Check for updates

Cite this: Chem. Sci., 2019, 10, 3324

๑ All publication charges for this article have been paid for by the Royal Society of Chemistry

Received 21st December 2018 Accepted 5th February 2019

DOI: $10.1039 / \mathrm{c} 8 \mathrm{sc} 05733 \mathrm{~h}$

rsc.li/chemical-science

\section{Site-selective nitrenoid insertions utilizing postfunctionalized bifunctional rhodium(II) catalysts $\uparrow$}

\author{
Jan-Philipp Berndt, ${ }^{a}$ Yevhenii Radchenko, ${ }^{a}$ Jonathan Becker, ${ }^{b}$ \\ Christian Logemann, (D) ${ }^{\text {b }}$ Dhaka R. Bhandari, ${ }^{\mathrm{b}}$ Radim Hrdina (iD) *a \\ and Peter R. Schreiner (D) *a
}

\begin{abstract}
We report a new strategy for the preparation of dirhodium(॥) complexes with the general formula $\operatorname{Rh}_{2}(A)_{4}$ that allows the isolation of a dirhodium tetracarboxylate complex with a free amino group available for postfunctionalization. The postfunctionalization of this complex enables the incorporation of a variety of functional groups, including double and triple bonds as well as nucleophilic moieties, thus paving the way to new classes of polymeric as well as bifunctional catalysts, and polymetallic complexes. Furthermore, we demonstrate that a urea containing dirhodium(॥) complex enables site-selective nitrenoid insertions by remote hydrogen bonding control.
\end{abstract}

\section{Introduction}

Dirhodium(II) complexes act as sensors, ${ }^{\mathbf{1}}$ show antitumor activity, ${ }^{2}$ are capable of cross-linking DNA, ${ }^{3}$ and can be used to control peptide structures by binding carboxylate side chains to the Rh core, ${ }^{4}$ thus enabling site-specific modifications of polypeptides and proteins. ${ }^{5}$ They act as Lewis acids to activate alkynes, ${ }^{6}$ as well as enynes ${ }^{7}$ or serve as hydrogenation catalysts. ${ }^{8}$ The well-known $\mathrm{Rh}(\mathrm{II})$ carbenoid $^{\mathbf{9}}$ and nitrenoid ${ }^{\mathbf{1 0}}$ transfer catalysts are capable of catalyzing $\mathrm{X}-\mathrm{H}$ insertions, ${ }^{\mathbf{1 1}}$ cyclopropanations, ${ }^{\mathbf{1 1 a}, \mathbf{1 2}}$ aziridinations, ${ }^{\mathbf{1 3}}$ ylide formation, ${ }^{\mathbf{1 1 a}, \mathbf{1 4}}$ and allylic oxidations. ${ }^{15}$ One of the main challenges in Rh(II) mediated carbenoid and nitrenoid insertions is the control of siteselectivity. ${ }^{16}$ Davies and coworkers tackled this issue by applying highly site-selective $\mathrm{Rh}$ (II) catalysts for carbenoid $\mathrm{C}-\mathrm{H}$ bond insertions. ${ }^{17}$ Bach's group designed a catalyst enabling hydrogen bonding of quinolones, to perform regio- and enantioselective $\mathrm{C}-\mathrm{H}$ aminations and aziridinations of these substrates. ${ }^{18}$ Generally, Rh(II) carboxylates, carboxamidates, and phosphates are prepared in two steps. ${ }^{19}$ The first represents the synthesis of the ligand, which is then subjected to ligand exchange. Early procedures for the preparation of $\mathrm{Rh}$ (II) carboxylates made use of $\mathrm{Rh}(\mathrm{OH})_{3}$ (ref. 20) or $\mathrm{Rh}(\mathrm{Cl})_{3}$ (ref. 21)

${ }^{a} J$ ustus Liebig University, Institute of Organic Chemistry, Heinrich-Buff-Ring 17, 35392 Giessen, Germany. E-mail: prs@uni-giessen.de; Radim.Hrdina@org.chemie. uni-giessen.de

${ }^{b}$ Institute of Inorganic and Analytical Chemistry, Heinrich-Buff-Ring 17, 35392 Giessen, Germany

$\dagger$ Electronic supplementary information (ESI) available: Detailed experimental procedures, characterization data and copies of ${ }^{1} \mathrm{H}$ and ${ }^{13} \mathrm{C}$ NMR spectra. CCDC 1852225-1852227. For ESI and crystallographic data in CIF or other electronic format see DOI: $10.1039 / \mathrm{c} 8 \mathrm{sc} 05733 \mathrm{~h}$ and large excess of the ligands. In 1992, a more atom economic protocol for the preparation of these complexes using $\mathrm{Rh}$ (II) carbonate, $^{22}$ was reported. ${ }^{23}$ Ball's group used cis-[ $\left[\mathrm{Rh}_{2}(\mathrm{tfa})_{2}(-\right.$ $\left.\mathrm{OAc}_{2}\right]$ as a precursor for the preparation of metalloenzymes by exchange of the trifluoroacetate ligands with peptide carboxylate side chains. ${ }^{4 a}$ The most widely used procedures subject ligands to an exchange with $\mathrm{Rh}$ (II) acetate, in which product formation is favored by removal of acetic acid. ${ }^{24}$ Functional groups such as unsaturated bonds or nucleophilic moieties are thereby not tolerated (for highly substituted ones see ref. $18 a$ and 25) because of the Lewis acidity of the Rh complex. ${ }^{26}$

Focusing on an alternative way to prepare functionalized $\mathrm{Rh}$ complexes, we decided to reverse the known approach by designing an appropriate spacer that is introduced first and allows efficient postfunctionalization, thereby enhancing the functional group diversity (Fig. 1). ${ }^{27}$

\section{Results and discussion}

The spacer has to bear an acid moiety for attachment to the complex and an additional functional group enabling postfunctionalization. We envisioned that amino acids may be excellent precursors, as the amino group allows efficient functionalization through amide bond formation. However, subjecting unprotected $\alpha$-amino acids to ligand exchange with $\mathrm{Rh}_{2}(\mathrm{OAc})_{4}$ is not possible as it results in complexes such as $\mathbf{1}$ involving the binding of the carboxylic acid and the amine to the $\mathrm{Rh}$ center (Scheme 1B). ${ }^{28}$ Amines irreversibly disrupt the carboxylate bridging structure, also intermolecularly, unless they are sterically crowded or the rhodium core is shielded. ${ }^{20,25,29}$ Hence, only a few examples of dirhodium complexes containing an amine have been reported. ${ }^{4 a}$ 
A:

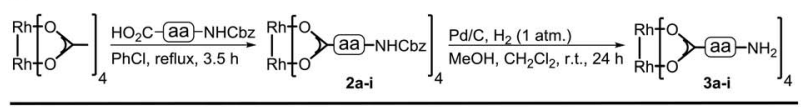

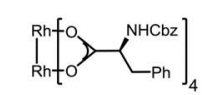

$2 \mathrm{a}^{[26]}$<smiles>CNC(C)(C)C1CCNC1</smiles>

$\underset{48 \%}{2 \mathrm{~d}}$

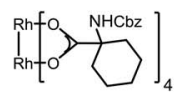

${ }_{78 \%}^{2 g}$
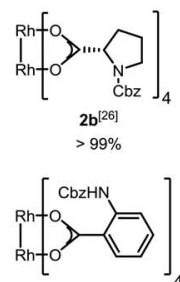

$52 \%$

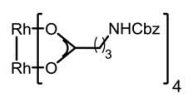

$2 \mathrm{~h}$
$75 \%$
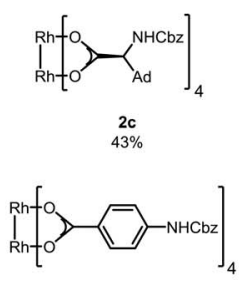

$\underset{63 \%}{2 f}$

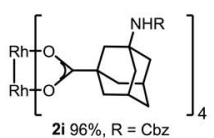

$2 i 96 \%, \mathrm{R}=\mathrm{Cbz}$
$3 i \mathrm{i} \% \%, \mathrm{R}=\mathrm{H}$

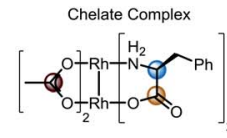
1 $\bigcirc_{191 \mathrm{ppm}} \bigcirc_{185 \mathrm{ppm}}$ $58 \mathrm{ppm}$

Bridged Carboxylate Complex

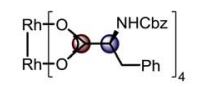

$2 \mathrm{a}$
$\mathrm{O} 191 \mathrm{ppm}$

O $57 \mathrm{ppm}$

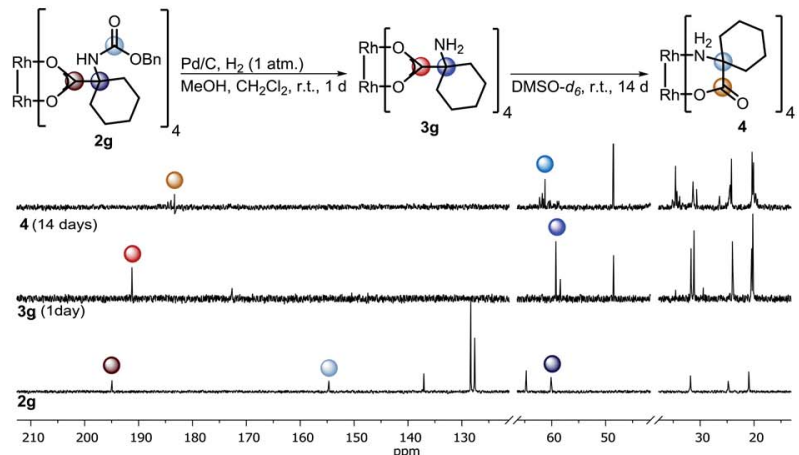

Scheme 1 (A) Preparation of the complexes 2a-i and subsequent hydrogenation; (B) top: characteristic ${ }^{13} \mathrm{C}-\mathrm{NMR}$ shifts of complex 1 (ref. $28 \mathrm{a}$ ) and dirhodium(॥) bridged carboxylate $4 \mathrm{a}$. Bottom: Hydrogenation of $\mathbf{2 g}$ to $\mathbf{3 g}$ and study of its time-dependent stability; NMR solvent: DMSO- $d_{6}$.

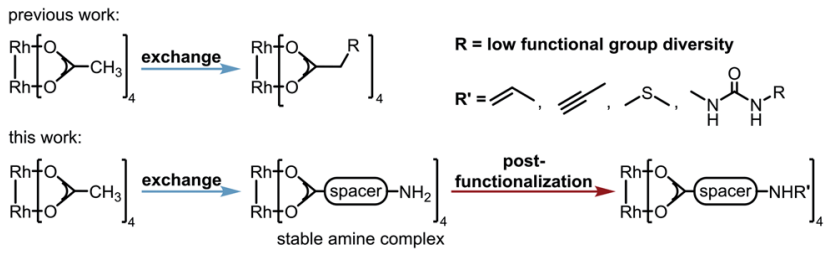

Fig. 1 New approach for the preparation of dirhodium(॥) complexes.

We decided to investigate the stability of a variety of $\mathrm{Rh}_{2}(\mathrm{~A})_{4}$ complexes containing amines. For this purpose, we envisioned to apply Cbz-protected (benzyloxycarbonyl) amino acids to a ligand exchange with $\mathrm{Rh}_{2}(\mathrm{OAc})_{4}$ and to cleave the $\mathrm{Cbz}$ group by hydrogenolysis subsequently (Scheme 1A). A variety of Cbz-protected amino acids were synthesized and subjected to ligand exchange using reported conditions. ${ }^{24 a}$ The novel dirhodium(II) carboxylates $2 \mathbf{a}-\mathbf{i}$ were obtained in yields up to $99 \%$. To our delight $\mathrm{Cbz}$ deprotection proceeded quantitatively. As anticipated, it was not possible to isolate complexes $\mathbf{3 a} \mathbf{a}-\mathbf{f}$, because of the presence of the free amino group leading to disruption of the bridged carboxylate structures. The stability of the deprotected complexes was studied with cyclohexyl derivative $\mathbf{3 g}$ (Scheme 1B) via time-dependent NMR. While hydrogenolysis of $2 \mathbf{g}$ was quantitative, ${ }^{13} \mathrm{C}-\mathrm{NMR}$ analysis of the reaction mixture revealed the disappearance of the $\mathrm{Cbz}$ group and appearance of the characteristic bridged carboxylate peak at $191 \mathrm{ppm}$ and an additional carbonyl peak at $173 \mathrm{ppm}$ (Scheme 1B). Thus, the spectrum indicates the presence of the desired complex $3 \mathrm{~g}$ and another compound. NMR analysis after 14 days showed the disappearance of both carbonyl peaks and rise of a new peak at 183 ppm, typical for complexes such as 1. We concluded that a sterically crowded ligand should suppress the decomposition of the complex and decided to use $\gamma$-aminoadamantane carboxylic acid S2. ${ }^{30}$ The bulky cage should shield the $\mathrm{Rh}$ core and prevent coordination to the metal by the sterically demanding amine. Indeed, deprotection of $\mathbf{2 i}$ resulted in formation of complex 3i containing a free amine. The use of $\gamma$ aminobutyric acid further supported the notion that steric bulk is the predominant factor for the design of suitable ligands.

Bench-stable complex $3 \mathbf{i}$ was used for postfunctionalization and optimization of the amide bond formation showed that $\mathrm{N}$ succinimidyl (OSu) acetate performed best, resulting in quantitative yield of tetra-acetylated S11 (Table S1 $\dagger$ ). The succinimidyl esters of 4-pentenoic acid, 4-pentynoic acid, and Boc-L-methionine (tert-butoxycarbonyl) were prepared by EDC-coupling. Postfunctionalization of $\mathbf{3 i}$ with the ester of 4-pentenoic acid afforded $77 \%$ of $\mathbf{5 a}$ (Scheme 2). The alkynyl containing complex $\mathbf{5 b}$ was isolated in comparable yield. A control experiment was performed by subjecting 1-alkynyl-3-adamantane carboxylic acid and $\mathrm{Rh}_{2}(\mathrm{OAc})_{4}$ to a thermal ligand exchange. The formation of the desired complex was not observed, but decomposition of the starting material occurred. These new complexes are particular valuable for functionalizations via Huisgen cyclization, ${ }^{31}$ thiolene chemistry ${ }^{32}$ or olefin metathesis. ${ }^{33}$
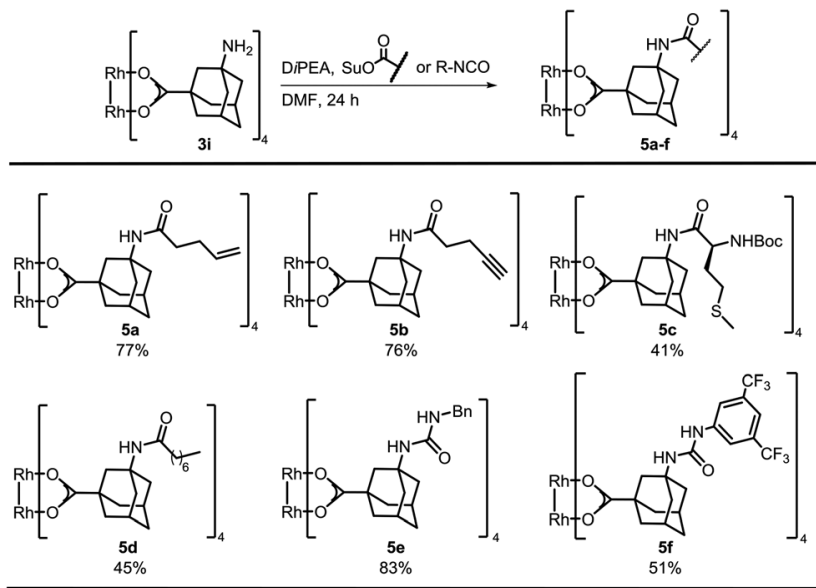

Scheme 2 Postfunctionalization of complex $3 \mathrm{i}$. 
Furthermore, we functionalized $\mathbf{3 i}$ with methionine. Carboxylic acid anhydrides can be employed instead of succinimidyl esters, as demonstrated with the synthesis of $\mathbf{5 d} \mathbf{d}^{\mathbf{3 4}}$ Isocyanates were used for the preparation of ureas, affording bifunctional Rh complexes 5e, f (Scheme 2). The structures of the urea complexes $\mathbf{5 e}$ and $\mathbf{5 f}$ were determined by crystal X-ray analysis. The ligands around the $\mathrm{Rh}-\mathrm{Rh}$ bond align in local $\mathrm{C}_{2}$-symmetry (Scheme 3$)^{35}$

One of the main challenges in Rh(II) mediated aziridinations, $\mathrm{C}-\mathrm{H}$ insertions, and cyclopropanations is the control of siteselectivity. Generally, aziridinations are faster than $\mathrm{C}-\mathrm{H}$ insertions if sulfamates or sulfonamides are used. ${ }^{9 b, 36}$ However, this trend can change, especially when $\mathrm{C}=\mathrm{C}$ bonds are sterically crowded or when sulfonimideamides are used as nitrene precursors. $^{37} \mathrm{Rh}(\mathrm{II})$ catalyzed nitrenoid and carbenoid $\mathrm{C}-\mathrm{H}$ insertions favor sites that stabilize positive charge. Thus, the reactivity scale for alkanes can be drawn as $3^{\circ}>$ benzylic $\sim \alpha$ heteroatom $>2^{\circ} \gg 1 .^{9 b, 36 a}$ However, catalyst design can alter this trend, e.g., sterically demanding catalysts favor insertions at sterically more accessible $\mathrm{C}-\mathrm{H}$ bonds. ${ }^{17 \boldsymbol{b}, \boldsymbol{c}, 36 a}$ As the selective functionalization of, e.g., polyenes, would "greatly streamline the synthesis of complex target molecules", ${ }^{16 b}$ we envisioned to apply bifunctional catalyst $\mathbf{5 f}$ in remote site-selective nitrenoid insertion directed by H-bonding. ${ }^{16 a, 18 a, 38}$ The non-covalent interactions between 5f, containing the key structural moiety 3,5-bis(trifluoromethyl)phenyl for H-bonding, ${ }^{39}$ and an acceptor, should create well-defined spatial relationships. We envisioned farnesol to be a worthwhile target for site-selective aziridination as it has three $\pi$-bonds possessing the reactivity trend $\mathrm{A}>\mathrm{B}>\mathrm{C}$ and nine allylic bonds, which may undergo $\mathrm{C}-\mathrm{H}$ insertion (Table 1$).{ }^{40}$ First we installed a hydrogen-bonding acceptor on farnesol by converting the alcohol to carbamate $\mathbf{6}$. We also performed a conformational analysis in the gas phase using U-GFN2-xTB on nitrenoid complex $5 f_{\mathbf{N}}$ with $\mathbf{6}^{41}$ Conformers entailing a reasonable alignment of $\mathbf{6}$ and $\mathbf{5} \mathbf{f}_{\mathbf{N}}$ were further optimized in toluene using GBSA as solvent model. ${ }^{42}$ Conformers at which the olefinic chain of $\mathbf{6}$ was oriented towards the outside of the cavity of $\mathbf{5 f}_{\mathbf{N}}$ were not considered as they do not lead to aziridination. The complex depicted in Scheme 4 is the energetically lowest-lying conformer. The computations place the shortest distance between nitrenoid and double bond $\mathrm{B}$ at $d\left(\mathrm{~N} \cdots \pi_{\mathrm{B}}\right)=3.43 \AA$,

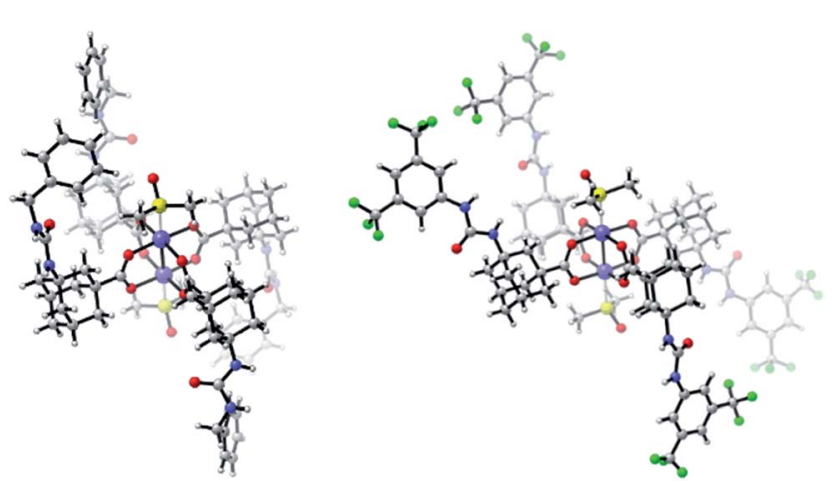

Scheme 3 X-Ray crystal structures $5 e$ (left) and $5 f$ (right), DMSO molecules coordinate the Rh atoms.
Table 1 Site-selective aziridination of farnesol carbamate $6^{a}$

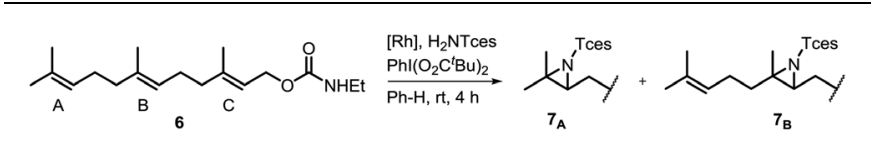

\begin{tabular}{lllll}
\hline Entry & Catalyst & $\mathbf{7}_{\mathbf{A}}: \mathbf{7}_{\mathbf{B}}{ }^{b}$ & Yield $\left(\mathbf{7}_{\mathbf{A}}+\mathbf{7}_{\mathbf{B}}\right) / \%$ & Conv. $(\mathbf{6})^{c} / \%$ \\
\hline 1 & $\mathrm{Rh}_{2}(\mathrm{esp})_{2}$ & $2.0: 1.0$ & 29 & 81 \\
2 & $\mathrm{Rh}_{2}\left(\mathrm{O}_{2} \mathrm{CAd}\right)_{4}$ & $1.4: 1.0$ & 30 & 55 \\
3 & $\mathrm{Rh}_{2}(\mathrm{OAc})_{4}$ & $1.2: 1.0$ & 14 & $<20$ \\
4 & $\mathbf{5 f}$ & $1.0: 1.9$ & 31 & 80 \\
$5^{d}$ & $\mathbf{5 f}$ & $1.0: 2.5$ & 22 & 85 \\
$6^{e}$ & $\mathbf{5 f}$ & $1.0: 5.0$ & 23 & 73 \\
$7^{d, f}$ & $\mathbf{5 f}$ & $1.0: 3.4$ & 38 & $100^{c}$ \\
$8^{d, g}$ & $\mathbf{5 f}$ & $1.0: 3.8$ & 31 & $100^{c}$ \\
$9^{d, h}$ & $\mathbf{5 f}$ & $1.0: 2.1$ & 28 & 82 \\
$10^{d, i}$ & $\mathbf{5 f}$ & $1.0: 3.6$ & 21 & 70 \\
$11^{d, i, j}$ & $\mathbf{5 f}$ & $1.0: 4.9$ & 20 & 74 \\
$12^{d, i, j, k}$ & $\mathbf{5 f}$ & $1.0: 3.6$ & 26 & 67 \\
$13^{e, i, j, l}$ & $\mathbf{5 f}$ & $1.0: 4.0$ & 40 & $100^{c}$ \\
$14^{l}$ & $\mathrm{Rh}$ & $1.1: 1.0$ & 42 & $100^{c}$ \\
$15^{e, m}$ & $\mathbf{5 f}$ & $1.0: 1.3$ & 11 & 57
\end{tabular}

${ }^{a}$ Conditions: 2 mol\% [Rh], $c=1.0 \mathrm{M}, 25{ }^{\circ} \mathrm{C}$, $\mathrm{Ph}-\mathrm{H}$, ratio of 6: $\mathrm{H}_{2}$ NTces : $\mathrm{PhI}\left(\mathrm{O}_{2} \mathrm{C}^{t} \mathrm{Bu}\right)_{2}(1: 1: 2) .{ }^{b} \mathrm{NMR}$ ratio. ${ }^{c}$ Based on reisolated starting material. ${ }^{d} c=0.05 \mathrm{M} .{ }^{e} c=0.01 \mathrm{M} .{ }^{f} 2$ equiv. $6 .{ }^{g} 1.5$ equiv. 6. ${ }^{h} \mathrm{PhI}\left(\mathrm{O}_{2} \mathrm{CC}(\mathrm{Me})_{2} \mathrm{Ph}\right)_{2}$ used. ${ }^{i} 1.2$ equiv. $\mathrm{PhI}\left(\mathrm{O}_{2} \mathrm{C}^{t} \mathrm{Bu}\right)_{2} .{ }^{j}{ }_{2.3}$ equiv. MgO. ${ }^{k} 8 \mathrm{~mol} \%$ 5f. ${ }^{l} 3.0$ equiv. 6. ${ }^{m} 10.0$ equiv. ethyl- $N$-ethyl carbamate.

followed by the least reactive double bond $\mathrm{C}$ at $d\left(\mathrm{~N} \cdots \pi_{\mathrm{C}}\right)=4.24$ $\AA$, and $d\left(\mathrm{~N} \cdots \pi_{\mathrm{A}}\right)=6.20 \AA$. Thus, based on steric arguments, catalyst $\mathbf{5 f}$ should favor double bond $\mathrm{B}$, although the intrinsic reactivity of 6 should lead to the aziridination of double bond A as the major product. We commenced our study by applying Du Bois conditions ${ }^{43}$ with commercially available sulfonamide $\mathrm{TcesNH}_{2}$ (2,2,2-trichloroethyl sulfamate). The aziridination of $\mathbf{6}$ with $\operatorname{bis}\left[\right.$ rhodium $\left(\alpha, \alpha, \alpha^{\prime}, \alpha^{\prime}\right.$-tetramethyl-1,3-benzenedipropionic acid)] $\left[\mathrm{Rh}_{2}(\mathrm{esp})_{2}\right]$ afforded a $2.0: 1.0\left(7_{\mathbf{A}}: 7_{\mathbf{B}}\right)$ ratio in favor of double bond A. Likewise, $\mathrm{Rh}_{2}(\mathrm{OAc})_{4}$ afforded a $1.2: 1.0$ ratio (Table 1). The aziridination of double bond $\mathrm{C}$ was not observed.

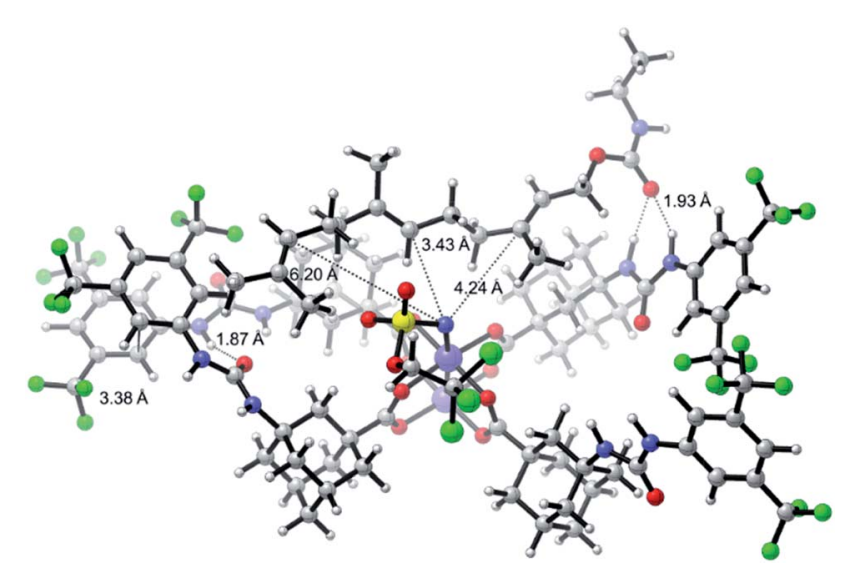

Scheme 4 U-GFN2-xTB optimized structure of the nitrenoid complex $5 f_{N}$ with carbamate 6 ; solvent model GBSA (toluene). 
Bifunctional catalyst 5 f favors double bond B with a 1.0 : 1.9 ratio, thereby overcoming the intrinsic reactivity of $\mathbf{6}$. Note that $\mathbf{5 f}$ exhibits the same reactivity as $\mathrm{Rh}_{2}(\mathrm{esp})_{2}$, which was designed to circumvent the lack of reactivity in intermolecular reactions. ${ }^{44}$ With tetrakis[1-adamantanecarboxylate] dirhodium(II) $\left[\mathrm{Rh}_{2}\left(\mathrm{O}_{2}\right.\right.$ CAd) $)_{4}$, a sterically similar bulky catalyst as compared to $\mathbf{5 f}$, but not capable of hydrogen bonding, we observed a $1.4: 1.0$ ratio in favor of the intrinsically preferred product $\mathbf{7}_{\mathbf{A}}$. Higher dilution should suppress the aziridination of substrate not bound to catalyst 5f, thereby enhancing the ratio. Indeed, lower concentrations improved the ratio to up to $1.0: 5.0$ (entry 6). Furthermore, $\mathrm{MgO}$ increased the ratio by scavenging the released pivalic acid (entries 10 and 11), which disturbs hydrogen bonding between catalyst $5 \mathbf{f}$ and $\mathbf{6}$. We underscored our hypothesis of hydrogen bonding between $5 \mathbf{f}$ and $\mathbf{6}$ by using 10 equiv. of ethyl- $N$ ethylcarbamate as additive. The additive interacts with the urea moiety of $\mathbf{5 f}$ and thus competes for the hydrogen bonding with the substrate. As a consequence, the ratio of $7_{\mathbf{A}}$ and $\mathbf{7}_{\mathbf{B}}$ decreased from $1.0: 5.0$ to $1.0: 1.3$ (entries 6 and 15). The optimized conditions catalysed by bifunctional complex $\mathbf{5 f}$ afforded $40 \%$ yield of $7_{\mathbf{A}}$ and $7_{\mathbf{B}}$ in a $1.0: 4.0$ ratio (entry 13 ). The catalysed aziridination utilizing benchmark catalyst $\mathrm{Rh}_{2}(\mathrm{esp})_{2}$, exhibiting an exceptionally high activity, ${ }^{\mathbf{4 4}}$ afforded a similar yield, but in a ratio of $1.1: 1.0\left(7_{\mathbf{A}}: 7_{\mathbf{B}}\right)$. The comparable yields of benchmark catalyst $\mathrm{Rh}_{2}(\mathrm{esp})_{2}$ and $\mathbf{5 f}$ confirm the high activity of $\mathbf{5 f}$. Note, catalyst $\mathbf{5} \mathbf{f}$ can be used to achieve unique selectivity in the aziridination of polyenes. This proof-of-concept expands the limited number of examples utilizing non-covalent interactions for control of site-selectivity ${ }^{16 a}$ and shows that the novel bifunctional catalysts can be used to overcome intrinsic substrate reactivities by remote hydrogen bonding.

Furthermore, we performed a competition experiment for the nitrenoid $\mathrm{C}-\mathrm{H}$ insertion of the benzylic position of Bocprotected amine $\mathbf{8}$ vs. ethylbenzene $\mathbf{9}$, to demonstrate substrate recognition of $\mathbf{5 f}$ via hydrogen bonding (Table 2). Benchmark catalyst $\mathrm{Rh}_{2}(\mathrm{esp})_{2}$ afforded about a $1: 1$ ratio for the two benzylic positions $\mathbf{8}_{\mathbf{B n}}$ and $\mathbf{1 0}$, whereas bifunctional catalyst 5f is capable of discriminating between these two benzylic positions, thereby favoring $\mathbf{8}_{\mathrm{Bn}}$ in a $1.6: 8.1$ ratio; $\mathrm{Rh}_{2}\left(\mathrm{O}_{2} \mathrm{CAd}\right)_{4}$, gave a $1: 1$ ratio. In accord with the reactivity trend, $\mathbf{8}_{\mathbf{N}}$ was observed as the minor product.

Table 2 Competitive $\mathrm{C}-\mathrm{H}$ insertion between ethylbenzene 9 and amine $8^{a}$

\begin{tabular}{|c|c|c|c|c|}
\hline 9 & & & 10 & ${ }_{B_{B n}}$ \\
\hline Catalyst & $\mathbf{8}_{\mathbf{N}}^{b}$ & $10^{b}$ & $\mathbf{8}_{\mathbf{B n}}{ }^{b}$ & $\operatorname{Yield}^{b} / \%$ \\
\hline $\mathrm{Rh}_{2}(\mathrm{esp})_{2}$ & 1.0 & 3.9 & 3.0 & 47 \\
\hline $\mathrm{Rh}_{2}\left(\mathrm{O}_{2} \mathrm{CAd}\right)_{4}$ & 1.0 & 1.1 & 1.1 & 7 \\
\hline $5 f$ & 1.0 & 1.6 & 8.1 & 12 \\
\hline
\end{tabular}

${ }^{a}$ Conditions: $0.4 \mathrm{mmol}$ scale, $2 \mathrm{~mol} \%[\mathrm{Rh}], 25^{\circ} \mathrm{C}, 4.0 \mathrm{~mL} \mathrm{Ph}-\mathrm{H}$, ratio of $8: 9: \mathrm{H}_{2} \mathrm{NTces}: \mathrm{PhI}\left(\mathrm{O}_{2} \mathrm{C}^{t} \mathrm{Bu}\right)_{2}: \mathrm{MgO}(1: 1: 1: 1.2: 2.3) .{ }^{b}$ Ratio and yield determined by NMR with internal standard.

\section{Conclusions}

We accomplished the isolation of the first stable $\mathrm{Rh}_{2}(\mathrm{~A})_{4}$ complex bearing a free amine. The acylation of this complex enables the incorporation of various functional groups. The bifunctional dirhodium complex was designed and tested in nitrenoid insertions. This catalyst is capable to overwrite the intrinsic reactivity of molecules by remote hydrogen bonding. Future work focuses on the application of other polyfunctional complexes prepared via this new procedure.

\section{Conflicts of interest}

There are no conflicts to declare.

\section{Acknowledgements}

This work was supported by LOEWE "SynChemBio" and by DFG (sp314/13-1). The authors thank S. Bernhardt for HPLC separations, S. Grimme for access to the GFN2-xTB code, and B. Spengler for access to MALDI measurements.

\section{Notes and references}

1 S. A. Hilderbrand, M. H. Lim and S. J. Lippard, J. Am. Chem. Soc., 2004, 126, 4972-4978.

2 (a) J. D. Aguirre, A. M. Angeles-Boza, A. Chouai, J.-P. Pellois, C. Turro and K. R. Dunbar, J. Am. Chem. Soc., 2009, 131, 11353-11360; (b) H. T. Chifotides and K. R. Dunbar, Acc. Chem. Res., 2005, 38, 146-156; (c) A. Erck, E. Sherwood, J. L. Bear and A. P. Kimball, Cancer Res., 1976, 36, 2204-2209.

3 (a) S. U. Dunham, H. T. Chifotides, S. Mikulski, A. E. Burr and K. R. Dunbar, Biochemistry, 2005, 44, 996-1003; (b) L. E. Joyce, J. D. Aguirre, A. M. Angeles-Boza, A. Chouai, P. K. L. Fu, K. R. Dunbar and C. Turro, Inorg. Chem., 2010, 49, 5371-5376.

4 (a) A. N. Zaykov, K. R. MacKenzie and Z. T. Ball, Chem.-Eur. J., 2009, 15, 8961-8965; (b) A. N. Zaykov, B. V. Popp and Z. T. Ball, Chem.-Eur. J., 2010, 16, 6651-6659.

5 Z. T. Ball, Acc. Chem. Res., 2013, 46, 560-570.

6 M. Yang, S. J. Odelberg, Z. Tong, D. Y. Li and R. E. Looper, Tetrahedron, 2013, 69, 5744-5750.

7 (a) K. Ota and N. Chatani, Chem. Commun., 2008, 2906-2907; (b) K. Ota, S. I. Lee, J.-M. Tang, M. Takachi, H. Nakai, T. Morimoto, H. Sakurai, K. Kataoka and N. Chatani, J. Am. Chem. Soc., 2009, 131, 15203-15211.

8 (a) P. Legzdins, G. L. Rempel and G. Wilkinson, J. Chem. Soc., Chem. Commun., 1969, 825; (b) B. C. Y. Hui, W. K. Teo and G. L. Rempel, Inorg. Chem., 1973, 12, 757-762.

9 (a) M. P. Doyle, R. Duffy, M. Ratnikov and L. Zhou, Chem. Rev., 2010, 110, 704-724; (b) H. M. L. Davies and D. Morton, Chem. Soc. Rev., 2011, 40, 1857-1869; (c) H. M. L. Davies and R. E. J. Beckwith, Chem. Rev., 2003, 103, 2861-2904.

10 (a) H. M. L. Davies and J. R. Manning, Nature, 2008, 451, 417424; (b) F. Collet, C. Lescot and P. Dauban, Chem. Soc. Rev., 
2011, 40, 1926-1936; (c) G. Dequirez, V. Pons and P. Dauban, Angew. Chem., Int. Ed., 2012, 51, 7384-7395.

11 (a) A. Ford, H. Miel, A. Ring, C. N. Slattery, A. R. Maguire and M. A. McKervey, Chem. Rev., 2015, 115, 9981-10080; (b) H. Lebel, C. Trudel and C. Spitz, Chem. Commun., 2012, 48, 7799-7801; (c) H. Lebel, L. Mamani Laparra, M. Khalifa, C. Trudel, C. Audubert, M. Szponarski, C. Dicaire Leduc, E. Azek and M. Ernzerhof, Org. Biomol. Chem., 2017, 15, 4144-4158.

12 H. Lebel, J.-F. Marcoux, C. Molinaro and A. B. Charette, Chem. Rev., 2003, 103, 977-1050.

13 (a) P. Müller and C. Fruit, Chem. Rev., 2003, 103, 2905-2920; (b) H. Lebel, K. Huard and S. Lectard, J. Am. Chem. Soc., 2005, 127, 14198-14199; (c) H. Lebel, C. Spitz, O. Leogane, C. Trudel and M. Parmentier, Org. Lett., 2011, 13, 5460-5463.

14 T. Ye and M. A. McKervey, Chem. Rev., 1994, 94, 1091-1160. 15 A. J. Catino, R. E. Forslund and M. P. Doyle, J. Am. Chem. Soc., 2004, 126, 13622-13623.

16 (a) H. J. Davis and R. J. Phipps, Chem. Sci., 2017, 8, 864-877; (b) Z. Huang and G. Dong, Acc. Chem. Res., 2017, 50, 465-471.

17 (a) K. Liao, T. C. Pickel, V. Boyarskikh, J. Bacsa, D. G. Musaev and H. M. L. Davies, Nature, 2017, 551, 609; (b) K. Liao, S. Negretti, D. G. Musaev, J. Bacsa and H. M. L. Davies, Nature, 2016, 533, 230; (c) C. Qin and H. M. L. Davies, J. Am. Chem. Soc., 2014, 136, 9792-9796; (d) K. Liao, W. Liu, Z. L. Niemeyer, Z. Ren, J. Bacsa, D. G. Musaev, M. S. Sigman and H. M. L. Davies, ACS Catal., 2018, 8, 678-682.

18 (a) T. Hoke, E. Herdtweck and T. Bach, Chem. Commun., 2013, 49, 8009-8011; (b) F. Zhong and T. Bach, Chem.-Eur. J., 2014, 20, 13522-13526.

19 (a) M. C. Pirrung and J. Zhang, Tetrahedron Lett., 1992, 33, 5987-5990; (b) R. Hrdina, L. Guénée, D. Moraleda and J. Lacour, Organometallics, 2013, 32, 473-479; (c) D. Poggiali, A. Homberg, T. Lathion, C. Piguet and J. Lacour, ACS Catal., 2016, 6, 4877-4881; (d) N. McCarthy, M. A. McKervey, T. Ye, M. McCann, E. Murphy and M. P. Doyle, Tetrahedron Lett., 1992, 33, 5983-5986; (e) D. M. Hodgson, D. A. Selden and A. G. Dossetter, Tetrahedron: Asymmetry, 2003, 14, 3841-3849; $(f)$ S. Kitagaki, M. Anada, O. Kataoka, K. Matsuno, C. Umeda, N. Watanabe and S.-i. Hashimoto, J. Am. Chem. Soc., 1999, 121, 1417-1418.

20 S. A. Johnson, H. R. Hunt and H. M. Neumann, Inorg. Chem., 1963, 2, 960-962.

21 P. A. Agaskar, F. A. Cotton, L. R. Falvello and S. Han, J. Am. Chem. Soc., 1986, 108, 1214-1223.

22 C. R. Wilson and H. Taube, Inorg. Chem., 1975, 14, 405-409. 23 G. H. P. Roos and M. A. McKervey, Synth. Commun., 1992, 22, 1751-1756.

24 (a) H. J. Callot and F. Metz, Tetrahedron, 1985, 41, 4495-4501; (b) M. P. Doyle, W. R. Winchester, J. A. A. Hoorn, V. Lynch, S. H. Simonsen and R. Ghosh, J. Am. Chem. Soc., 1993, 115, 9968-9978.
25 T. Itoh, M. Kondo, H. Sakamoto, K. Wakabayashi, M. Kanaike, K. Itami and S. Masaoka, Dalton Trans., 2015, 44, 15334-15342.

26 R. T. Buck, D. M. Coe, M. J. Drysdale, L. Ferris, D. Haigh, C. J. Moody, N. D. Pearson and J. B. Sanghera, Tetrahedron: Asymmetry, 2003, 14, 791-816.

27 H. Yang, P. Srivastava, C. Zhang and J. C. Lewis, ChemBioChem, 2014, 15, 223-227.

28 (a) N. R. Candeias, C. Carias, L. F. R. Gomes, V. André, M. T. Duarte, P. M. P. Gois and C. A. M. Afonso, Adv. Synth. Catal., 2012, 354, 2921-2927; (b) R. F. M. Frade, N. R. Candeias, C. M. M. Duarte, V. André, M. Teresa Duarte, P. M. P. Gois and C. A. M. Afonso, Bioorg. Med. Chem. Lett., 2010, 20, 3413-3415.

29 J. Jaźwiński, J. Mol. Struct., 2005, 750, 7-17.

30 L. Wanka, C. Cabrele, M. Vanejews and P. R. Schreiner, Eur.

J. Org. Chem., 2007, 1474-1490.

31 J. E. Hein and V. V. Fokin, Chem. Soc. Rev., 2010, 39, 13021315.

32 C. E. Hoyle and C. N. Bowman, Angew. Chem., Int. Ed., 2010, 49, 1540-1573.

33 Y. Dong, J. B. Matson and K. J. Edgar, Biomacromolecules, 2017, 18, 1661-1676.

34 Please note that $\mathrm{Rh}_{2}(\mathrm{~A})_{4}$ complexes containing amide moiety can be prepared by thermal ligand exchange (see ref. 26).

35 (a) H. M. L. Davies, P. R. Bruzinski, D. H. Lake, N. Kong and M. J. Fall, J. Am. Chem. Soc., 1996, 118, 6897-6907; (b) J. Hansen and H. M. L. Davies, Coord. Chem. Rev., 2008, 252, 545-555.

36 (a) K. W. Fiori, C. G. Espino, B. H. Brodsky and J. Du Bois, Tetrahedron, 2009, 65, 3042-3051; (b) K. Guthikonda, P. M. Wehn, B. J. Caliando and J. Du Bois, Tetrahedron, 2006, 62, 11331-11342.

37 (a) C. Liang, F. Robert-Peillard, C. Fruit, P. Müller, R. H. Dodd and P. Dauban, Angew. Chem., Int. Ed., 2006, 45, 4641-4644; (b) C. Liang, F. Collet, F. Robert-Peillard, P. Müller, R. H. Dodd and P. Dauban, J. Am. Chem. Soc., 2008, 130, 343-350.

38 Selected reviews on bifunctional ligands in metal catalysis; (a) S. Carboni, C. Gennari, L. Pignataro and U. Piarulli, Dalton Trans., 2011, 40, 4355-4373; (b) P. Dydio and J. N. H. Reek, Chem. Sci., 2014, 5, 2135-2145; (c) M. Raynal, P. Ballester, A. Vidal-Ferran and P. W. N. M. van Leeuwen, Chem. Soc. Rev., 2014, 43, 1660-1733; (d) Y. Kuninobu, Synlett, 2018, 29, 2093-2107; selected examples on urea directed transistion metal catalysis: (e) Y. Kuninobu, H. Ida, M. Nishi and M. Kanai, Nat. Chem., 2015, 7, 712; ( $f$ ) J. Wen, X. Fan, R. Tan, H.-C. Chien, Q. Zhou, L. W. Chung and X. Zhang, Org. Lett., 2018, 20, 2143-2147.

39 (a) K. M. Lippert, K. Hof, D. Gerbig, D. Ley, H. Hausmann, S. Guenther and P. R. Schreiner, Eur. J. Org. Chem., 2012, 2012, 5919-5927; (b) G. Jakab, C. Tancon, Z. Zhang, K. M. Lippert and P. R. Schreiner, Org. Lett., 2012, 14, 1724-1727.

40 P. A. Lichtor and S. J. Miller, Nat. Chem., 2012, 4, 990. 
41 For GFN-xTB see: S. Grimme, C. Bannwarth and P. Shushkov, J. Chem. Theory Comput., 2017, 13, 1989-2009. GFN2-xTB will be published soon by Grimme and coworkers. 42 Benzene is not included in the GFN2-xTB code, thus toluene was used.
43 K. W. Fiori and J. Du Bois, J. Am. Chem. Soc., 2007, 129, 562568.

44 C. G. Espino, K. W. Fiori, M. Kim and J. Du Bois, J. Am. Chem. Soc., 2004, 126, 15378-15379. 